\title{
Prototype of Control and Monitor System with Fuzzy Logic Method for Smart Greenhouse
}

\author{
D Kurniawan ${ }^{1}$, A Witanti ${ }^{2}$ \\ 1,2 Faculty of Information Technology, University of Mercu Buana Yogyakarta, \\ Indonesia \\ E-mail: didikboy96@gmail.com¹, aritawitanti@mercubuana-yogya.ac.id ${ }^{2}$
}

Submitted: 31 December 2020, revised: 19 February 2021, accepted: 20 February 2021

\begin{abstract}
Abstrak. Untuk meningkatkan produktivitas tanaman diperlukan bangunan greenhouse yang dapat melindungi tanaman dari faktor eksternal dan terintegrasi dengan sistem pintar yang dapat di monitor kapan saja dan di mana saja, serta dapat memenuhi kebutuhan tanaman yang optimal secara otomatis. Pada penelitian ini dibangun sistem yang dapat memantau kondisi greenhouse secara realtime di mana saja melalui aplikasi Blynk dengan konsep IoT, serta sistem yang dapat mengendalikan output secara otomatis dengan metode fuzzy logic. Fokus kendali pada penelitian ini adalah durasi penyiraman air dengan Mini Water Pump dan pengaturan intensitas cahaya dengan LED Strip. Sistem ini juga dibekali dengan FAN yang dapat aktif saat suhu $31^{\circ} \mathrm{C}$ atau lebih. Parameter yang digunakan dalam sistem ini adalah sensor DHT22 (suhu dan kelembapan udara), sensor Soil Moisture (kelembapan tanah), sensor Water Level (ketinggian air), sensor LDR (intensitas cahaya) dan RTC DS3231 (Real Time Clock), yang dikendalikan dengan mikrokontroler Arduino Mega 2560. Pada hasil pengujian didapatkan akurasi pada fuzzy logic water pump sebesar $98.3 \%$ dan akurasi pada fuzzy logic LED Strip sebesar $99.6 \%$. Pada hasil pengujian terhadap parameter yang ada, didapatkan hasil pembacaan yang cukup optimal.
\end{abstract}

Kata kunci: Greenhouse; Fuzzy Logic; Blynk; Arduino Mega 2560; IoT.

\begin{abstract}
To increase plant productivity, greenhouse buildings are needed to protect plants from external factors. The greenhouse also needs integrated smart systems that can be used to monitor the building anytime and from anywhere and to provide optimal plant needs automatically. In this research, a system was built to monitor greenhouse conditions in real time from anywhere through Blynk application with IoT concept, as well as a system that can control output automatically with fuzzy logic method. The focus of control on this research is the duration of the watering using Mini Water Pump and light intensity setting using LED Strip. This system is also equipped with FAN that will be active when the temperature is $31^{\circ} \mathrm{C}$ or more. Parameters used in this system are DHT22 sensor (air temperature and humidity), Soil Moisture sensor, Water Level sensor, LDR sensor (light intensity) and RTC DS3231 (Real Time Clock), which are controlled using Arduino Mega 2560 microcontroller. The test results showed the accuracy of fuzzy logic water pump by $98.3 \%$ and accuracy of fuzzy logic LED Strip by $99.6 \%$. Based on the test on the parameters, it shows that the result is fairly optimal.
\end{abstract}

Keywords: Greenhouse; Fuzzy Logic; Blynk; Arduino Mega 2560; IoT. 


\section{Introduction}

Greenhouse is a closed structure that provides a microclimate for plant growth [1]. Greenhouse is a building designed to protect plants from the influence of the surrounding environment, such as pest disturbances, extreme weather, extreme temperatures, and others that can inhibit crop productivity. A good greenhouse should be able to meet the standards of plant needs, ranging from good air circulation, smooth irrigation to adequate lighting.

Many factors can affect plant growth such as temperature, humidity, soil moisture, as well as light intensity. The need to maintain stability in the greenhouse is something that must be well-considered because each plant has different environmental needs. Therefore, an automatic control and monitor system is needed to facilitate the stability of the greenhouse.

The Arduino Mega 2560 that integrated with DHT22 sensors, Soil Moisture sensors and LDR sensors, enables the system to read the temperature, the humidity, the soil moisture, and the light intensity conditions inside the greenhouse. Then, it will transmit sensor readings to users through the Blynk application with the IoT (Internet of Things) concept. As additional inputs, Water Level sensor measures the water level to determine the duration of watering. RTC DS3231 (Real Time Clock) functions as a timer on the system, as well as a timer parameter to control the system output at night. Fuzzy Logic method with Mamdani calculation is used as control logic in Mini Water Pump and LED Strip output. Fuzzy Logic Mamdani is one of the methods that is very flexible and have tolerance to existing data. Mamdani method is also called min-max method that is able to take the minimum and maximum membership value so that it can be applied to sales optimization with easier and cheaper calculations [2]. To be able to adjust the brightness level on the LED Strip, this experiment applied the PWM (Pulse Width Modulation) method. PWM is a way of manipulating the signal width expressed with pulses in one period to obtain different average voltages [3].

Research on smart greenhouse systems has been conducted several times, such as the research "Controlling Smart Green House Using Fuzzy Logic Method", with the sensor used is a DHT11 sensor to read the temperature and humidity of the air [4]. The other research is "Light Intensity Control System, Air Temperature and Humidity In Raspberry PI Based Greenhouse", with sensors used are air temperature and humidity sensor (DHT11) and light intensity sensor (LDR)" [5].

\section{Theoretical Framework}

\subsection{Greenhouse System}

The term greenhouse comes from the words "green" and "house", which means home for plants. It is named greenhouse because when seen from the outside, the greenhouse which walls are made from glass or plastic will appear green. At first the greenhouse walls were made of glass, so it is called as a glasshouse, but the term glasshouse is often identical to environmental pollution. In the further development, the glass material of greenhouse wall is replaced with plastic [5].

Greenhouse systems are designed in different forms for different climatic conditions. One plant has certain conditions that help the plant to thrive and be more productive. Climate adjustment in greenhouses should be optimized through systems that can create the same climate as needed to grow the crops [6].

\subsection{Temperature and Relative Humidity}

Plant growth is strongly influenced by temperature and humidity. If the humidity of the environment is over the limits, then the plant growth will not be optimum. Each group of plants needs different air humidity for its optimal development. The ideal humidity for plant growth is about $60 \%$ to $80 \%$. Besides that, air temperature also affects plant life activities such as in the process of photosynthesis, respiration, transpiration, growth, pollination, fertilization, and absorption. The significance of this temperature is related to other factors such as humidity, the availability of water, and the ideal temperature for plant growth ranging from $15^{\circ} \mathrm{C}$ to $40^{\circ} \mathrm{C}$ [7].

\subsection{Soil Moisture}

Soil moisture is water that fills part or all of the pores of the soil above the water table [8]. Another definition states that soil moisture indicates the amount of water stored between the pores of the soil. 
Soil moisture is very dynamic, this is caused by the evaporation through soil level, transpiration and percolation [9].

\subsection{Light Intensity}

Light means a lot to plants, mainly because of its role in physiological activities such as photosynthesis, respiration, growth and flowering, opening and closing of stomata, germination and plant growth. Irradiation of the sun affects the growth, reproduction and yield of plants through the process of photosynthesis. The absorption of light by pigments will affect the division of photosynthate to other parts of the plant through the process of photomorphogenesis [10].

\subsection{Arduino Mega 2560}

Arduino is an open-source hardware prototype platform based on flexible and easy-to-use hardware and software. Arduino is intended for artists, designers, and anyone interested in creating interactive objects or environments [11].

The technical data board of Arduino Mega2560 is addressed in Table 1 as the following:

Table 1. Datasheet Board Arduino Mega 2560

\begin{tabular}{ll}
\hline \multicolumn{1}{c}{ Description } & \\
\hline Microcontroller Chip & ATmega2560 \\
Operating voltage & $5 \mathrm{~V}$ \\
Input voltage (that recommended, via DC jack) & $7 \mathrm{~V}-12 \mathrm{~V}$ \\
Input voltage (limit, via DC jack) & $6 \mathrm{~V}-20 \mathrm{~V}$ \\
Digital I/O pin & $54 \mathrm{pcs}$, including providing PWM \\
Analog input pin & $16 \mathrm{pcs}$ \\
DC current per I/O pin & $20 \mathrm{~mA}$ \\
Current DC pin 3.3V & $50 \mathrm{~mA}$ \\
Memory Flash & $256 \mathrm{~KB}, 8 \mathrm{~KB}$ has been used for bootloader \\
SRAM & $8 \mathrm{~KB}$ \\
EEPROM & $4 \mathrm{~KB}$ \\
Clock Speed & $16 \mathrm{MHz}$ \\
Dimensions & $101.5 \mathrm{~mm} \times 53.4 \mathrm{~mm}$ \\
Weight & $37 \mathrm{~g}$ \\
\hline
\end{tabular}

\subsection{DHT22 Sensor}

DHT22 is a digital sensor of relative humidity and temperature. DHT22 sensors use capacitors and thermistors to measure the surrounding air and signal output on the data pin. DHT22 is claimed to have good reading quality, judged by the rapid response of the data acquisition process and its minimalist size, as well as the relatively cheap price when compared to other thermohydrometer tools [12].

\subsection{Soil Moisture Sensor}

The soil moisture sensor consists of two probes used to measure the volumetric content of water. Both probes allow currents to pass through the soil and then get resistance values to measure moisture values. When there is more water, the soil will do more electricity which means that there will be less resistance. Therefore, the humidity level will be higher [13].

\subsection{Water Level Sensor}

Water Level Sensor is a tool used to signal the alarm/automation panel that the water level has reached a certain level. The sensor will give a dry contact signal (NO/NC) to the panel. Water level detector by reading the voltage value generated by each voltage division circuit composed by four outputs [14]. 


\subsection{LDR Sensor}

LDR or light Dependent Resistor is one type of resistor which resistance value is influenced by the light received. The amount of resistance value on the LDR depends on the amount of light received by the LDR itself. Light-sensitive resistors or photoresistors are electronic components which resistance will decrease when the light intensity that hits the component increases. Photoresistor may also refer to light-dependent resistors (LDRs), or conductor [5].

\subsection{RTC DS3231}

DS3231 is a cheap and accurate real-time I2C clock with Temperature Compensated Crystal Oscillator (TCXO) which crystals are integrated. On this device there are inputs for batteries that serve to maintain accurate punctuality when the main power to the device is disconnected. The integration of crystal resonators improves the long-term accuracy of the device as well as reduces the number of pieces inside the manufacturing line. The DS3231 is available in commercial and industrial temperature ranges, and is offered in an 800-mile or 300-mile SO package [15].

\subsection{Fuzzy Logic}

Fuzzy logic is a development of a technology that no longer uses conventional means to obtain the desired results by using mathematical equations. Instead, it applies a system of human ability to control something, namely in the form of rules: If - then (If - Then Rules). Therefore, the control process will follow the approach linguistically. This system is called fuzzy logic control system, where the fuzzy logic control system has no dependence on variables - control process variables. The system is developed in the field of control engineering, especially for nonlinen and dynamic systems [16].

Fuzzy logic system consists of three stages namely fuzzification, fuzzy rule and defuzzification (output in the form of calculation results) converted to a certain value. Fuzzy input membership function determines the variables such as temperature and humidity to develop controls and to minimize microcontroller memory data [13]. The mechanism of inference system in this research is addressed in Figure 1.

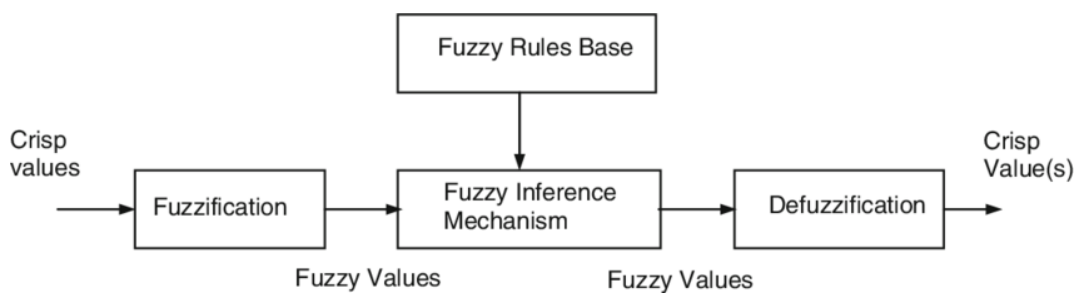

Figure 1. Fuzzy Logic Inference System

\section{Membership Function}

In functional form, membership degrees are expressed as certain mathematical functions. To know the degree of membership of each element in the conversation, the universe requires calculation. Mathematical functions that are usually used is trapezoidal functions. Trapezoidal membership in this study is shown in Figure 2 below.

$$
\operatorname{Trapezoid}(\mathrm{x}, \mathrm{a}, \mathrm{b}, \mathrm{c}, \mathrm{d})=\left\{\begin{array}{cl}
0, & x \leq a \\
\frac{x-a}{b-a}, & a \leq x \leq b \\
1, & b \leq x \leq c \\
\frac{d-x}{d-c}, & c \leq x \leq d \\
0, & d \leq x
\end{array}\right.
$$




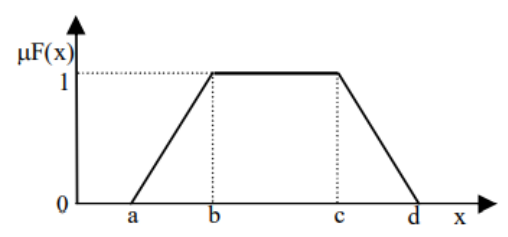

Figure 2. Trapezoid Membership

The fuzzification process is used to convert the enter data firmly into the form of membership degree. The knowledge base is used to connect the input set with the output set. Decision-making logic is used to combine the rules contained in the rule base into a mapping of a fuzzy set of inputs to a fuzzy set of outputs.

\section{Inference Mechanism}

Fuzzy inference applies fuzzy rules to fuzzy input then evaluates each rule. The fuzzy logic principle is used to combine the IF-THEN rules contained in the rule base into a mapping of a fuzzy input set to a fuzzy output set. Decision-making logic is the second step in fuzzy logic processing. There are several methods of decision making in fuzzy logic including the Mamdani method. The implication function uses MIN in decision making by Mamdani method and MAX in doing composition. This method of composition is often called MAX-MIN. Fuzzy Inference in this study is shown in Figure 3 below.

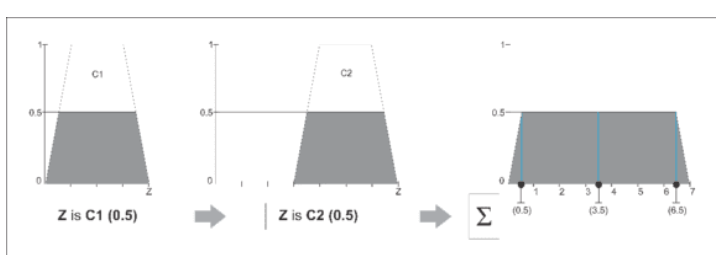

Figure 3. Fuzzy Inference Based Mamdani Method

\section{Defuzzification}

Input from the defuzzification process is a fuzzy set obtained from the composition of fuzzy rules, while the resulting output is a number in the domain of the fuzzy set. So, if given a set of fuzzy in a certain range, it must be taken a certain crisp value as its output. Defuzzification in this study is shown in Figure 4 below.

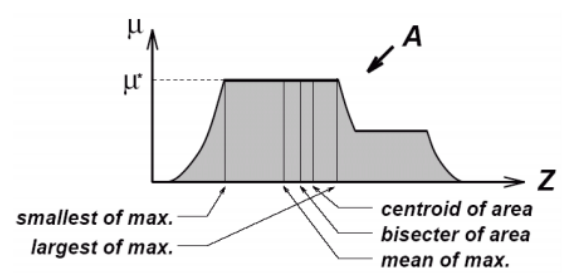

Figure 4. Defuzzification

\section{Methodology}

The material needed to make a greenhouse material are wood beams, PVC boards and plastic mica $0.50 \mathrm{~mm}$, with dimensions on the greenhouse is a length $=40 \mathrm{~cm}$, width $=25 \mathrm{~cm}$, height $=35 \mathrm{~cm}$. To create a program that will be planted on the Board Arduino Mega 2560, the greenhouse requires programming software or text editor called Arduino IDE (Integrated Development Environment) which uses $C$ language as the programming language. Fuzzy logic method is used to control water pump with the variables of temperature, humidity, soil moisture and water level, and to control LED strip with the variable of light intensity. Then, it will be controlled using logic IF-Else with set value IF temperature $\geq 31$ then FAN HIGH/ON, EIse FAN LOW/OFF. The system flowchart in this study is shown in Figure 5 below. 


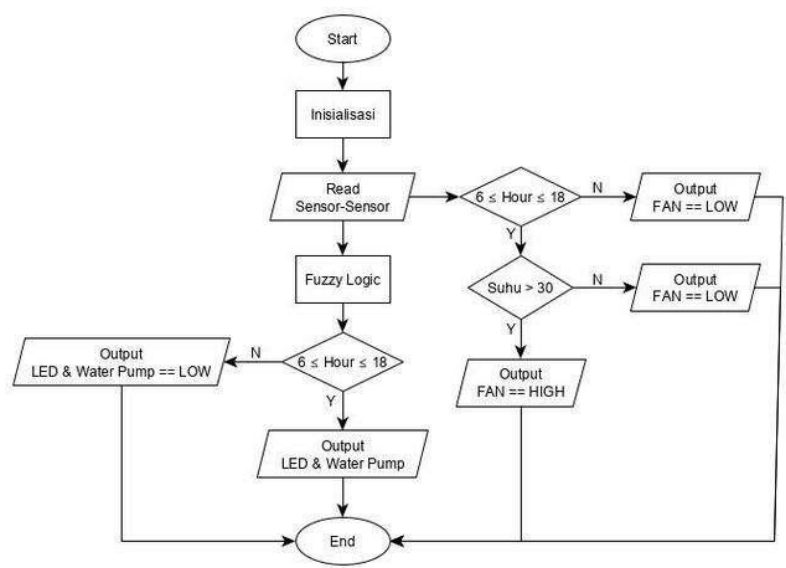

Figure 5. System Flowchart

\subsection{Circuit Design}

At this stage, the design is carried out on the entire electronic hardware series, consisting of system inputs circuits, system output circuits, processing circuits, voltage regulators, power supply and wiring. The circuit design in this study is shown in Figure 6 below.

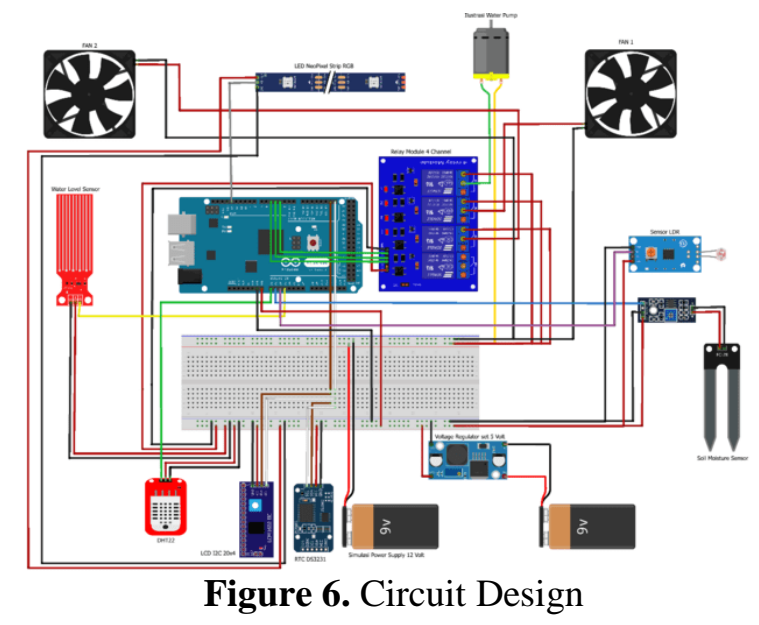

\subsection{Blok Diagram Design}

A control system consists of several components and a block diagram is used to show the function of each component. A block diagram of a system is an image representation of the functions performed by each component and its signal flow. This diagram illustrates the relationships between different components. Unlike abstract mathematical representations, block charts have advantages because they can describe more realistically the flow of signals from the actual system. In block diagrams, all system variables are connected to each other through functional blocks. The block diagram of this study is shown in Figure 7 below.

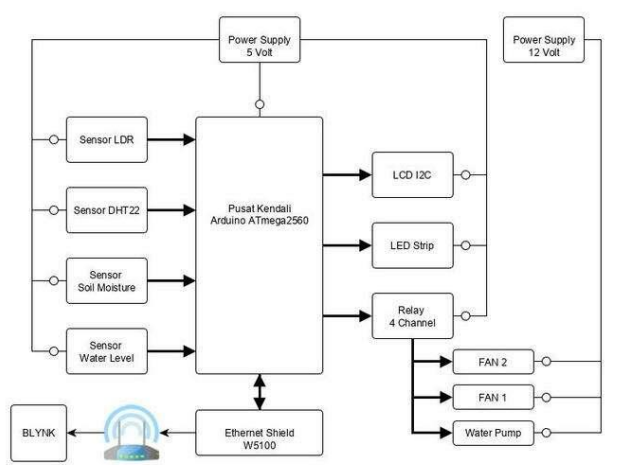

Figure 7. Blok Diagram Design 


\subsection{Fuzzy Water Pump Set}

The fuzzy Mamdani method for water pump control uses four input variables and one output variable with 48 fuzzy rules, as follows:

1. Input Variable of Temperature Input variables temperature will be divided into several sets of fuzzy set namely, cold, normal and hot, with the value range of $0-50$, as shown in Figure 8 below.

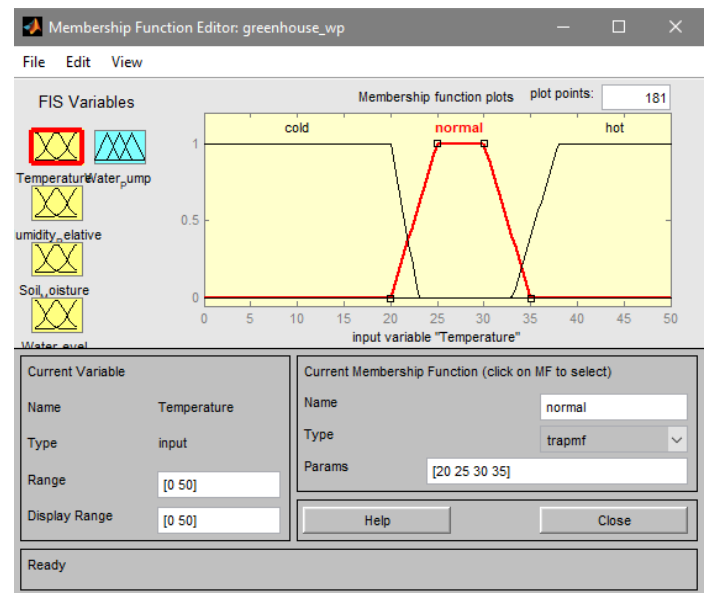

Figure 8. Temperature Variable

2. Input Variable of Relative Humidity

The input variable of air humidity $(\mathrm{RH})$ will be divided into several fuzzy sets namely, low, medium, and high, with the value range of $0-100$ as shown in Figure 9 below.

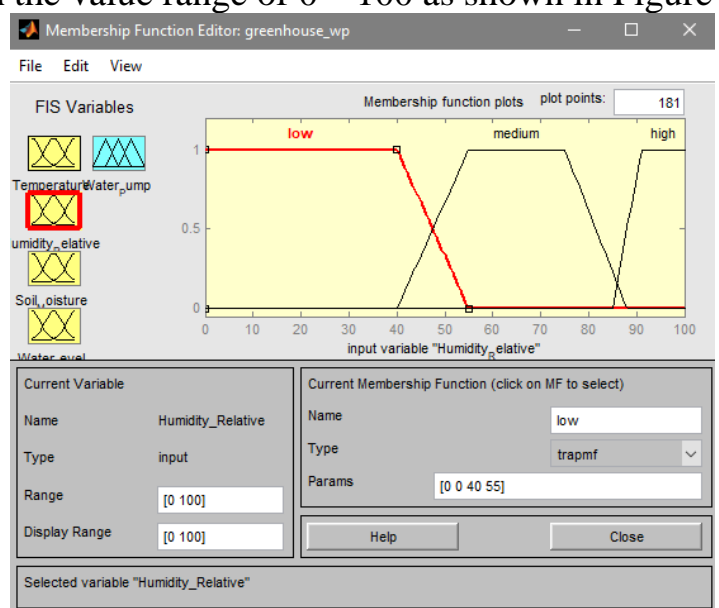

Figure 9. Variable of Relative Humidity

3. Input Variable of Soil Moisture

Soil Moisture input variables will be divided into several sets of fuzzy namely, dry, quite dry, normal, and saturated, with the value range of $0-100$ as shown in Figure 10 below: 


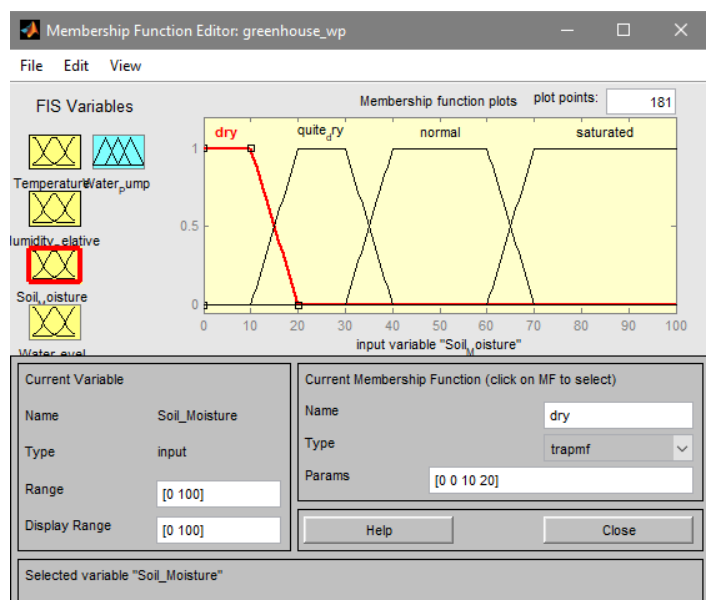

Figure 10. Variable of Soil Moisture

4. Input Variable of Water Level

Water Level input variables will be divided into several fuzzy sets namely, zero, water low, water medium and full, with the value range of $0-100$ as shown in Figure 11 below:

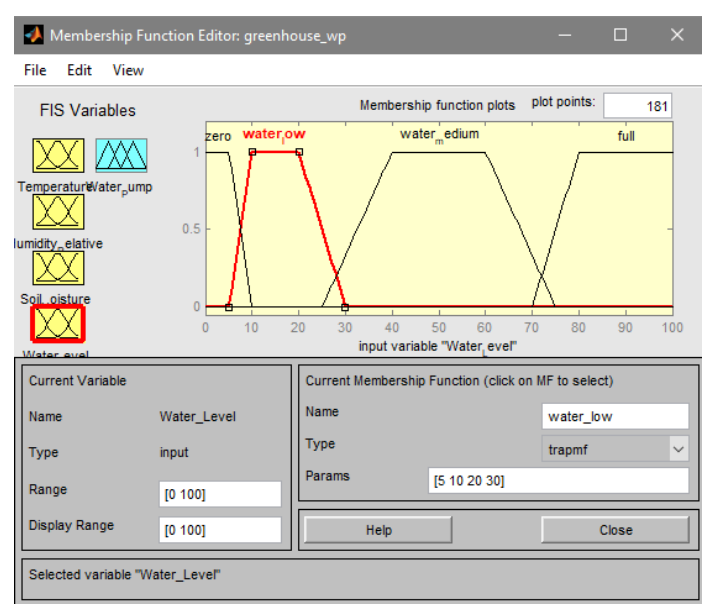

Figure 11. Variable of Water Level

5. Output Variable of Water Pump

Output variable water pump will be divided into several fuzzy sets namely off, short, rather, and long, with the watering duration range of $0-10$ as shown in Figure 12 below:

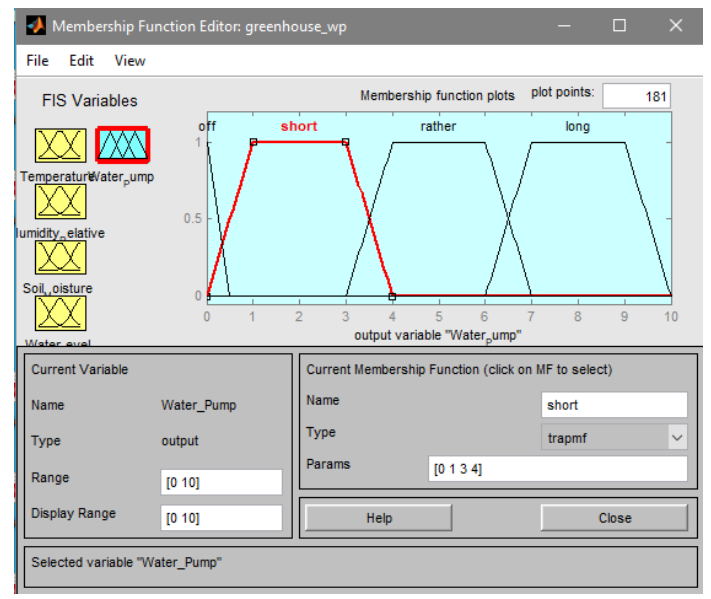

Figure 12. Variable of Water Pump 


\section{Fuzzy Rule of Water Pump}

After the input and output variables are made along with the membership value, then the rule base is made to determine the decision on the control of the water pump, as shown in Figure 13 below:

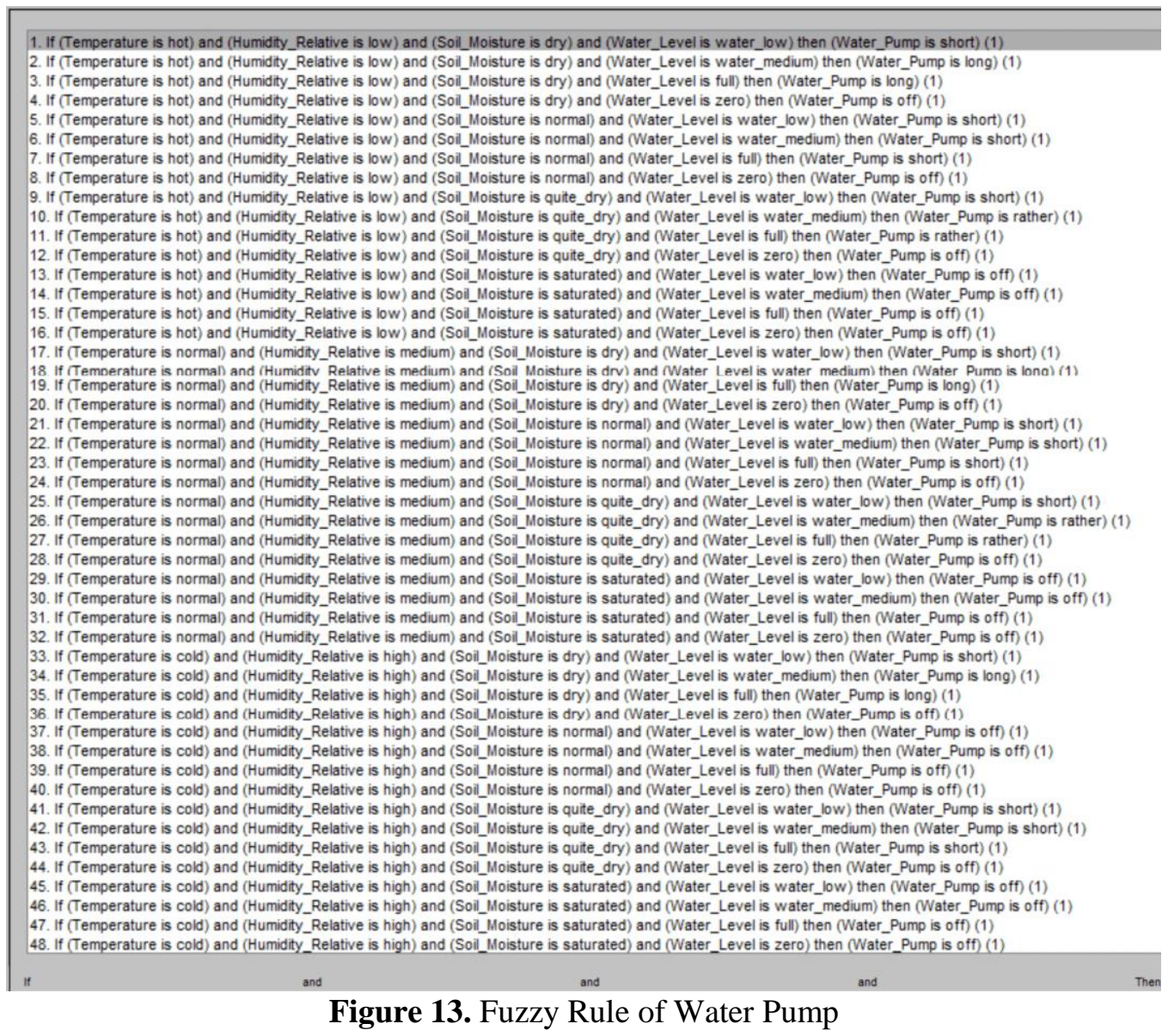

\subsection{Fuzzy Logic LED Strip Set}

This fuzzy Mamdani method for LED control uses one input variable and one output variable with five fuzzy rules, as follows:

1. Input Variable of Light Intensity

Variable Light Intensity will be divided into several fuzzy sets namely dark1, dark2, remang, remang2 and terang, with the value range of $0-1000$ as shown in Figure 14 below:

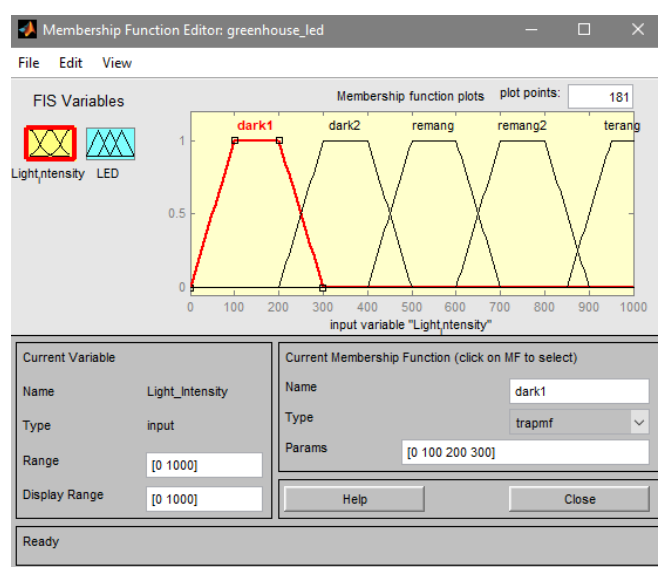

Figure 14. Variable of Light Intensity 


\section{Output Variable of LED}

LED variables will be divided into several fuzzy sets namely redup, remang2, remang1, terang2 and terang1, with the value range of $0-1000$ as shown in Figure 15 below:

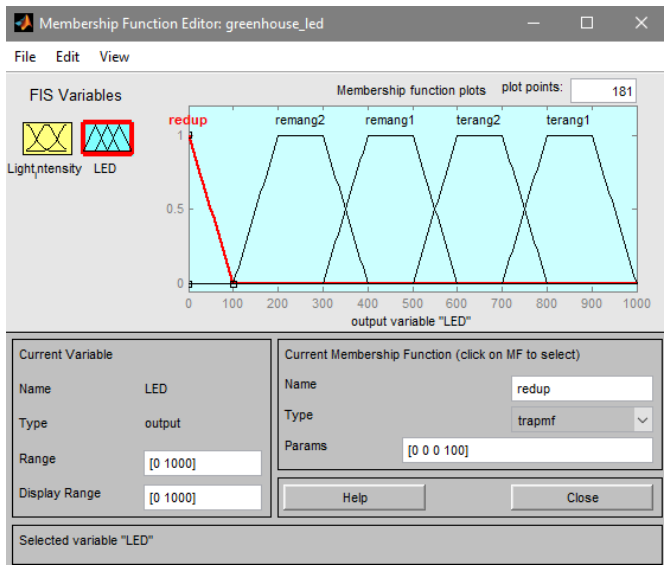

Figure 15. Variable of LED

\section{Fuzzy Rule LED}

After the input and output variables are made along with the membership value, then the rule base is made to determine the decision on the control of the LED Strip, as shown in Figure 16 below:

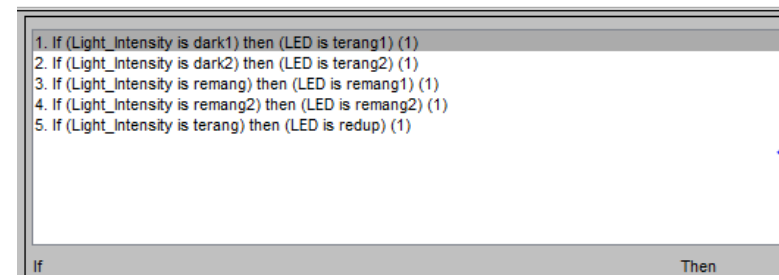

Figure 16. Fuzzy Rule LED

\section{Result and Discussion}

\subsection{Fuzzy Logic Testing}

This stage is to find out the suitability of fuzzy logic results in Greenhouse with Fuzzy Logic on Matlab through 10 tests. As shown in Table 2 and Table 3 below, the percentage calculation of accuracy is obtained from the division of the smallest value (Min) in the fuzzy ratio with the largest value (Max) then multiplied by $100 \%$.

$$
\text { Accuracy }=\frac{\text { Min Value }}{\text { Max Value }} \times 100 \%
$$

Table 2. Fuzzy Logic Water Pump Testing

\begin{tabular}{|c|c|c|c|c|c|c|c|}
\hline \multirow[t]{2}{*}{ No. } & TEMP & RH & $\begin{array}{c}\text { SOIL } \\
\text { MOISTURE }\end{array}$ & $\begin{array}{l}\text { WATER } \\
\text { LEVEL }\end{array}$ & $\begin{array}{c}\text { FUZZY } \\
\text { GREENHOUSE }\end{array}$ & $\begin{array}{c}\text { FUZZY } \\
\text { MATLAB }\end{array}$ & $\begin{array}{l}\text { ACCUR } \\
\text { ACY }\end{array}$ \\
\hline & ${ }^{\circ} \mathbf{C}$ & \multicolumn{3}{|c|}{$\%$} & \multicolumn{2}{|c|}{ Second $(s)$} & $\%$ \\
\hline 1 & 31 & 66 & 0 & 0 & 0.17 & 0.143 & 84.1 \\
\hline 2 & 31 & 65 & 0 & 17 & 2.0 & 2.0 & 100.0 \\
\hline 3 & 31 & 65 & 10 & 18 & 2.0 & 2.0 & 100.0 \\
\hline 4 & 31 & 66 & 54 & 21 & 2.0 & 2.0 & 100.0 \\
\hline 5 & 30.9 & 68.2 & 0.0 & 31.0 & 8.0 & 8.0 & 100.0 \\
\hline 6 & 30.8 & 68.7 & 8.0 & 32 & 8.0 & 8.0 & 100.0 \\
\hline 7 & 30.7 & 68.9 & 17 & 34 & 6.06 & 6.03 & 99.5 \\
\hline 8 & 30.9 & 69.1 & 18.0 & 34.0 & 5.81 & 5.77 & 99.3 \\
\hline 9 & 32.1 & 66.2 & 20 & 35.0 & 5.0 & 5.0 & 100.0 \\
\hline 10 & 33.0 & 63.6 & 50.0 & 35.0 & 2.0 & 2.0 & 100.0 \\
\hline
\end{tabular}


Table 3. Fuzzy Logic LED Testing

\begin{tabular}{ccccc}
\hline \multirow{2}{*}{ No. } & LUX INTENSITY & $\begin{array}{c}\text { FUZZY } \\
\text { GREENHOUSE }\end{array}$ & $\begin{array}{c}\text { FUZZY } \\
\text { MATLAB }\end{array}$ & ACCURACY \\
\cline { 3 - 5 } & & \multicolumn{2}{c}{ LED Brightness } & \% \\
\hline 1 & 523 & 450 & 450 & 100.0 \\
2 & 498 & 455.85 & 455 & 99.8 \\
3 & 78 & 850 & 850 & 100.0 \\
4 & 57 & 850 & 850 & 100.0 \\
5 & 218 & 808.5 & 810 & 99.8 \\
6 & 213 & 818.4 & 820 & 99.8 \\
7 & 693 & 269.2 & 267 & 99.2 \\
8 & 689 & 278.9 & 276 & 99.0 \\
9 & 801 & 250 & 250 & 100.0 \\
10 & 688 & 281.2 & 278 & 98.9 \\
\hline \multicolumn{5}{c}{ Average Accuracy }
\end{tabular}

\subsection{RTC Testing}

This stage is to find out the suitability of the results of the time schedule that has been in the program based on the timing of the RTC against the entire output of the system. T previous system flow has discussed that all output in the greenhouse system will be in sleep mode when the time on the RTC shows at $18.00-06.00$ or $6 \mathrm{pm}$ to $6 \mathrm{am}$, as shown in Table 4 below:

Table 4. RTC Testing

\begin{tabular}{ccccccccccc}
\hline No. & RTC & Temp & RH & SM & WL & Lux & $\begin{array}{c}\text { Water } \\
\text { Pump }\end{array}$ & LED & FAN & Result \\
\hline 1 & $05: 55$ & 42.9 & 55.7 & 0.0 & Medium & 181 & OFF & OFF & OFF & OK \\
2 & $06: 05$ & 41.7 & 47.7 & 0.0 & Medium & 173 & 8.0 & 850 & ON & OK \\
3 & $17: 55$ & 39.1 & 49.9 & 0.0 & Medium & 143 & 8.0 & 850 & ON & OK \\
4 & $18: 00$ & 38.7 & 52.5 & 0.0 & Medium & 115 & OFF & OFF & OFF & OK \\
5 & $19: 00$ & 40.8 & 48.6 & 0.0 & Medium & 1 & OFF & OFF & OFF & OK \\
\hline
\end{tabular}

\subsection{User Interface View}

There are two user interfaces in this application, namely the user interface in Blynk application that must be connected to the internet network and the 20x4 LCD user interface that do not have to be connected to the internet network. This can be seen in Figure 17 below:

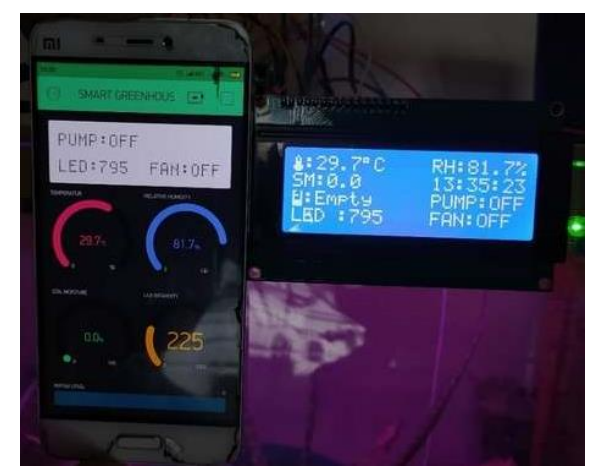

Figure 17. User Interface

\section{Conclusion}

Based on the results of tests that have been done 10 times against Fuzzy Logic Water Pump on Smart Greenhouse compared to Fuzzy Logic on Matlab, it was obtained an accuracy value of $98.3 \%$, and testing of Fuzzy Logic LEDs on Smart Greenhouse compared to Fuzzy Logic on Matlab, obtained an accuracy value of $99.6 \%$. Based on the test results against RTC that will be used as a timer on Water Pump, LED and FAN, get the appropriate results. 


\section{References}

[1] V. S. Jahnavi and S. F. Ahamed, "Smart Wireless Sensor Network for Automated Greenhouse,” IETE J. Res., vol. 61, no. 2, pp. 180-185, Mar. 2015.

[2] J. E. Informatika and T. Mary, "Jurnal Edik Informatika."

[3] R. I. S. and H. Hartono, "Rancang Bangun Pulse Width Modulation (PWM) Sebagai Pengatur Kecepatan Motor DC Berbasis Mikrokontroler Arduino," J. Penelit., vol. 3, no. 1, pp. 50-58, 2018.

[4] R. Syam, W. H. Piarah, and B. Jaelani, "Controlling Smart Green House Using Fuzzy Logic Method," Int. J. Smart Mater. Mechatronics, vol. 2, no. 2, pp. 116-120, 2016.

[5] R. Friadi and J. Junadhi, "Sistem Kontrol Intensitas Cahaya, Suhu dan Kelembaban Udara Pada Greenhouse Berbasis Raspberry PI," J. Technopreneursh. Inf. Syst., vol. 2, no. 1, pp. 3037, 2019.

[6] A. Wardani, "Purwarupa Perangkat IoT untuk Smart Greenhouse Berbasis Mikrokontroler," eProceeding Eng., vol. 5, no. 2, pp. 3859-3875, 2018.

[7] M. Jur et al., "PEMBERIAN CAHAYA TAMBAHAN DENGAN LAMPU HID DAN LED UNTUK MERESPON WAKTU PEMBUNGAAN TOMAT CHERRY (Solanum Liycopersicum var cerasiforme) DI DALAM RUMAH TANAMAN," Cocos, vol. 1, no. 8, 2017.

[8] Lutfiyana, N. Hudallah, and A. Suryanto, "Rancang Bangun Alat Ukur Suhu Tanah, Kelembaban Tanah, dan Resistansi," J. Tek. Elektro, vol. 9, no. 2, pp. 80-86, 2017.

[9] I. A. Saputro, J. E. Suseno, and E. Widodo, "Rancang bangun sistem pengaturan kelembaban tanah secara real time menggunakan mikrokontroler dan diakses di web," Youngster Phys. J., vol. 6, no. 1, pp. 40-47, 2017.

[10] I. Susilawati, Wardah, "Pengaruh Berbagai Intensitas Cahaya Terhadap Pertumbuhan Semai Cempaka (Michelia champaca L.) Di Persemaian,” J. For. ISSN 1693 - 5179, vol. 14, no. 1, pp. 59-66, 2016.

[11] J. Arifin, L. N. Zulita, and Hermawansyah, "Perancangan Murottal Otomatis Menggunakan Mikrokontroller Arduino Mega 2560," J. Media Infotama, vol. 12, no. 1, pp. 89-98, 2016.

[12] F. Puspasari, T. P. Satya, U. Y. Oktiawati, I. Fahrurrozi, and H. Prisyanti, "Analisis Akurasi Sistem sensor DHT22 berbasis Arduino terhadap Thermohygrometer Standar," J. Fis. dan Apl., vol. 16, no. 1, p. 40, 2020.

[13] A. R. Putri, Suroso, and Nasron, "Perancangan Alat Penyiram Tanaman Otomatis pada Miniatur Greenhouse Berbasis IOT," Semin. Nas. Inov. dan Apl. Teknol. di Ind. 2019, pp. 155$159,2019$.

[14] U. S. Khair, "Alat Pendeteksi Ketinggian Air Dan Keran Otomatis Menggunakan Water Level Sensor Berbasis Arduino Uno," Wahana Inov. J. Penelit. dan Pengabdi. Masy. UISU, vol. 9, no. 1, pp. 9-15, 2020.

[15] Y. Widiawati, P. H. Islam, J. T. Elektro, P. N. Jakarta, and I. L. Belakang, "Pemanfaatan RTC ( Real Time Clock ) DS3231 Untuk Menghemat Daya," Pros. Semin. Nas. Tek. Elektro, vol. 3, pp. 287-289, 2018.

[16] R. N. Farid, S. Karim, G. Eddy, and W. Pratama, "STUDI PENERAPAN FUZZY LOGIC PADA PENGATURAN KECEPATAN MOTOR DC MENGGUNAKAN ARDUINO UNO AT 328," vol. 2, no. 1, pp. 33-42, 2016. 